\title{
Found Money? SPlit-Award Statutes and Settlement OF Punitive Damages Cases
}

\author{
by
}

Andrew F. Daughety and Jennifer F. Reinganum

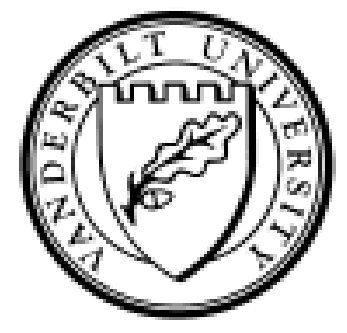

Working Paper No. 00-W01R

January 2000

Revised March 2001

\section{DEPARTMENT OF ECONOMICS \\ VANDERBILT UNIVERSITY \\ NASHVILLE, TN 37235}

www.vanderbilt.edu/econ 


\title{
Found Money? Split-Award Statutes and Settlement of Punitive Damages Cases
}

\author{
Andrew F. Daughety and Jennifer F. Reinganum*
}

January 2000

Revised: March 2001

* We thank audiences at Duke University, the Southeast Theory and International Economics Meetings, the Southern Economic Association Meetings, Michael D. Green, Keith Hylton, Craig Kelinson, Mitch Polinsky, Eric Posner, Jesse Schwartz and Tom Ulen. This paper replaces a previous working paper entitled "Settlement Bargaining and the Incentive to Misrepresent Product Safety," which benefitted from support under NSF grants SBR-9223087 and SBR-9596193. 


\title{
Found Money? Split-Award Statutes and Settlement of Punitive Damages Cases
}

\author{
Andrew F. Daughety and Jennifer F. Reinganum
}

\begin{abstract}
We examine the effect of "split-award" statutes (wherein the State takes a share of a punitive damages award) on equilibrium settlements and the incentives to go to trial. We find that split-award statutes simultaneously lower settlement amounts and the likelihood of trial, as both parties act to cut out the State. We develop an analysis of the revenue that split-award statutes could generate, conditioned on the allocation of punitive damages between the plaintiff, his lawyer and the State. We determine the revenue-maximizing share and find that it is robust to variations in economic parameters and to whether the state's share is gross or net of the plaintiff's attorney's fee. One surprising result is that these statutes need not deter filings and that their use can encourage plaintiffs' attorneys to pursue weaker cases than would otherwise be brought. We discuss possible objectives for the states currently employing split-award procedures.
\end{abstract}




\section{INTRODUCTION}

In this paper we extend and combine existing asymmetric information bargaining models to provide a positive analysis of the effect of the "split-award" tort reform on equilibrium settlements and the incentives to go to trial. Split-award statutes allocate a proportion of punitive damages awards won by successful plaintiffs to the State. We show that, holding filings constant, sharing with the State results in more settlements at lower amounts. Settlement acts to cut out the State, which only gets a share of punitive damages awards made at trial. This means that, unless trial awards increase to account for this effect, sharing results in decreased incentives for care by defendants. Thus the State, which typically sets the sharing rate by statute, may have an incentive to set the rate so as to affect the frequency of trial. The setting of the rate could be motivated primarily by a belief that defendants are over-deterred or it could be motivated primarily by State revenue considerations; both of these motives have been raised in support of split-award statutes. We find that the theoretical model (which accounts for the State as an active player) predicts a sharing rate for an expected revenue-maximizing state that is reasonably consistent with over one-half of the rates observed in practice. By considering other punitive damages reform policies prevailing in those states employing split-award statutes, we infer that over two-thirds of the states seem more consistent with a revenue maximization, rather than a deterrence reduction, hypothesis. We also find that split-award statutes need not, by themselves, reduce incentives for filing, but may actually encourage the filing of weak cases that would not have been filed absent the statute.

Iowa provides a good example of the application of a split-award statute. On June 24, 1992, Pat McCartt and Tonya Naughton were awarded the largest punitive damages verdict made to that point in a state court in Iowa. ${ }^{1}$ The basis for the award was that the management of the Cantebury Inn, a Best Western affiliate near the University of Iowa campus where McCartt and Naughton had 
taken a room one night in 1988, had failed to properly ensure privacy. More precisely, the room they had rented (the hotel's penthouse facility with Jacuzzi and other "things you don't find in a hotel room in Iowa") had a two-way mirror covering a hole in the wall separating the room from a crawl space, which they discovered after they "heard noise from time to time on the other side of the wall."

Tort reform in Iowa provides that the State share the punitive damages award. The Iowa statute specifies that the plaintiff is to receive $25 \%$ of the punitive damages award, with the remainder (net of the plaintiff's attorney's fees) going to a civil reparations trust fund for "purposes of indigent civil litigation programs or insurance assistance programs." ${ }^{2}$ Other reforms that many states have used have included limits ("caps") on compensatory or punitive damages awards, bifurcation of trials so as to have separate hearings on punitive damages, and higher evidentiary standards for making such awards. The oft-stated motivation for reform is the perception that punitive damages were out of control, excessive and contributing to a mounting crisis in insurance rates, that this was driven by greedy plaintiffs looking for a windfall and that this was contributing to a lack of competitiveness of U.S. products abroad. However, at least in the case of split-award statutes, another motivation seems worth examining: raising revenue for the State.

The plan of the paper is as follows. In the next section we briefly review the arguments for splitting punitive damages awards with the State and discuss the variety of split-award procedures that have been implemented by the eight states that use them; we also briefly discuss the existing (rather sparse) literature. Section 3 provides an intuitive discussion of how we model settlement bargaining under incomplete information; the details of the analysis are provided in the Appendix. Our analysis extends the standard bargaining models to account for contingent fees for the plaintiff's attorney, the share of the award taken by the State and the alternative ways that the statutes allocate 
payoffs to all players. Section 4 addresses the basis on which the State might choose a sharing rate, focusing on revenue maximization. We find that the State's revenue-maximizing rate is very robust to different parameter values and schemes for allocating the punitive damages award among the plaintiff, the plaintiff's attorney and the State, though it is somewhat sensitive to the form of the bargaining process itself. In Section 5 we examine the impact of split-award statutes on the incentives of plaintiffs' attorneys to accept and pursue cases. While a split-award statute may lower the attorney's expected revenue for a suit, we find that the increased incentive for the plaintiff to settle provides a countervailing cost-saving effect, with the net result that more suits have a positive expected value (for the attorney) with a split-award statute than without one. We then use these results, along with information on other tort reforms adopted, to discuss possible objectives for the states currently employing split-award procedures. Section 6 provides a brief summary and the Appendix provides technical details.

\section{PUNITIVE DAMAGES AND THE SPLIT-AWARD TORT LAW STATUTES}

Punitive damages awards are traditionally believed to further two goals: deterrence and retribution (see, e.g., Owen, 1994, and Sunstein, et. al., 1998). They have been the source of intense political and academic debate with respect to appropriateness and efficiency as well as frequency of use, magnitude and predictability. ${ }^{3}$ Many states have instituted reforms presumably to reduce the likelihood of awards being made (e.g., by increasing evidentiary standards) and to limit incentives to seek such awards (e.g., caps and split-award statutes).

Reform efforts, however, are not only attributable to the belief that awards are enormous and plaintiffs are drawn to suits so as to make fortunes (presumably requiring the agreement of juries and 
judges along the path). One further basis for reform that is particularly relevant to the split-award statute is the perspective that since punitive damages concern behavior which is (potentially or actually) socially undesirable and which causes a social harm, this implies that society may deserve compensation and that punitive damages should go to the State to compensate society for the social harm, and not to the individual plaintiff who is presumably being compensated for their particular loss. ${ }^{4}$ Thus sharing awards with the State is rationalized, though this usually stops short of complete confiscation (since it is the individual who brings the suit, it is usually argued that some incentive must be provided for "private attorneys general activity" on the part of the plaintiff). ${ }^{5}$

Alaska, Georgia, Illinois, Indiana, Iowa, Missouri, Oregon and Utah all have some type of split-award statutes. ${ }^{6}$ These statutes vary with respect to the fraction of the award the State takes, how attorney's fees are accounted, the classes of cases to which the statute applies and where the State's share will go. ${ }^{7}$ Table 1 below summarizes the statutes currently in force. The eight states currently employing split-award statutes are listed in the left-hand column; of these, only Missouri applies less than a "clear and convincing" standard for punitive damages. The second and third column indicate the allocation of awards among the State, the victorious plaintiff and his attorney; the fourth column indicates how the funds are used.

Place Table 1 about here

\section{Literature Review}

The legal literature on split-award provisions has primarily focused on the constitutional implications of such statutes, especially with respect to uncompensated takings and excessive fines. ${ }^{8}$ To the best of our knowledge, Kahan and Tuckman (1995) provide the only paper that sets about 
formally analyzing the economic effects of split-award statutes on litigant choices. ${ }^{9}$ They consider effort choice by each litigant, possibly influenced by agency effects and different implementations of attorney cost-coverage in the different split-award statutes. They find that (in the absence of agency effects) split-award statutes reduce both the expected award paid by the defendant and the plaintiff's litigation expenses, while in the presence of agency problems this may not hold. They are unable to always characterize unambiguously the impact of splitting awards on settlement. This is for two reasons. First, they employ what is sometimes referred to as an "optimism" (or inconsistent priors) model wherein litigants behave in a non-Bayesian manner when confronted by differences of opinion about case outcomes. ${ }^{10}$ In this case, settlement behavior is not modeled explicitly; rather, settlement occurs whenever the "settlement range" exists. Thus the "likelihood" of settlement is either zero or one, and there isn't a unique prediction about the amount of the settlement.

We focus instead on modeling the strategic aspects of the negotiation process, which yields an intermediate likelihood of settlement and a unique predicted settlement amount, for each specification of the negotiation process. Since the predicted outcome depends on this specification, we consider the two polar cases of signaling and screening which are commonly used in the settlement literature, as well as a random proposer model which incorporates both. If the statute specifies that the State shares the award, then this will naturally encourage the two litigants to adjust their negotiation behavior, and marginal changes in the statute will result in marginal changes in equilibrium outcomes. This allows us to embed the settlement bargaining analysis in a larger model in which the sharing rate itself is subject to choice.

Second, Kahan and Tuckman consider two scenarios involving the criteria for settlement. In the first, a case is settled based on the joint payoff of the plaintiff and his attorney, while in the second 
a case is settled based on the payoff of the plaintiff's attorney alone. We assume that the plaintiff alone decides whether to settle, while the plaintiff's attorney decides whether to accept a case. Under this assumption, we obtain an unambiguous prediction that split-award statutes encourage settlement. $\underline{\text { Positive and Normative Considerations }}$

As mentioned earlier, this paper provides a positive, rather than normative, analysis of splitaward statutes. It is quite possible that, in a normative analysis, split-award statutes may be inferior instruments both for raising revenue and for optimizing deterrence. With respect to the issue of raising revenue, see Kaplow and Shavell (1994) arguing that using the legal system to redistribute income is dominated by using an income tax, and Sanchirico (2000) arguing that social optimality generally implies the active use of multiple means of redistributing income, including the legal system. Moreover, in a second-best outcome such as one characterized by over-deterrence, a split-award statute could both raise revenue for the state and simultaneously improve welfare (by reducing overdeterrence). As shown in Section 5, whether one concludes that deterrence is reduced as a secondary consequence of revenue-raising or whether revenue is raised as a secondary consequence of deterrence-reduction would seem to turn on the actual level of the plaintiff's share that is specified in the statute, as well as other punitive damages reforms that a state adopts.

With respect to optimizing deterrence, Polinsky and Che (1991) define a decoupled liability system as "one in which the award to the plaintiff differs from the payment by the defendant;" both Polinsky and Che and Kahan and Tuckman refer to split-award statues as an instance of decoupling. However, in order to use decoupling to provide optimal incentives to both parties, Polinsky and Che show that the award and the payment must typically be completely unlinked: one must be able to separately vary the award and the payment in order to simultaneously optimize the plaintiff's and 
defendant's incentives for suit and care, respectively. The optimal award to the plaintiff may be higher or lower than the optimal payment for the defendant, and thus the State might take some of the payment or contribute to the award. This level of fine-tuning is infeasible under split-award statutes, in which the payment and award are very much linked though not necessarily equal (Illinois comes closest by relying on judicial discretion), and while the State may receive part of the payment, these statutes contain no provision for the State to contribute to the award.

\section{MODELING SETTLEMENT BARGAINING}

Our analysis presumes that there is a risk-neutral plaintiff (denoted P) and a risk-neutral defendant (denoted D) and that, while much is commonly known, only D knows the true probability that he will be found liable for gross negligence (this probability is called his "type") and made to pay punitive damages, should the case go to trial. Trial is not assured, however, since the two litigants can bargain over a settlement. Since there is asymmetric information (only D knows his type), it is appropriate to model settlement bargaining using non-cooperative game theory. This is because the presence of asymmetric information may lead to a breakdown in bargaining and recourse to trial, thereby resulting in some inefficiency. As is now standard in this literature, we model bargaining as an "ultimatum" game, wherein one of the parties makes a settlement offer and the other party then responds by either accepting or rejecting the offer. ${ }^{11}$ Either choice ends the game since acceptance leads to an immediate transfer from $\mathrm{D}$ to $\mathrm{P}$ while rejection leads to trial, which also involves an immediate transfer from D to P. Two such incomplete information ultimatum games are possible. If $\mathrm{D}$ makes the offer and $\mathrm{P}$ is to respond, this is a signaling game, since $\mathrm{D}$ is the informed player; the reverse sequence is a screening game. We will analyze both of these games because: 1) the pair of 
incomplete information ultimatum games potentially provides upper and lower bounds on the litigants' equilibrium payoffs and 2) this allows us to properly construct a "random proposer" analysis of settlement with which to analyze the State's choice of sharing rate and the impact of split-award statutes on filings. Thus, we can implicitly accommodate a variety of possible bargaining scenarios, since the two ultimatum games represent the extreme contrasts of who has been assigned "power" in making or demanding a settlement transfer.

The following notation will be used in both the signaling and screening models. Let $\pi$ denote the probability that $\mathrm{D}$ will be found negligent (i.e., liable for compensatory damages), and let $\delta$ denote the amount of compensatory damages in that event. Let $\theta$ denote the probability that, conditional on being found negligent, $\mathrm{D}$ is also found to be grossly negligent (i.e., liable for punitive damages); let $\Delta$ denote the amount of punitive damages. ${ }^{12}$ We assume that $\pi, \delta$ and $\Delta$ are common knowledge to both $\mathrm{P}$ and $\mathrm{D}$, but that $\theta$ is private information on the part of $\mathrm{D}$ (as indicated earlier, this is $\mathrm{D}$ 's type). It is common knowledge that $\mathrm{P}$ knows only that $\theta$ is distributed on the interval $[0,1]$ according to the cumulative distribution function $\mathrm{H}(\theta)$; we assume that $\mathrm{H}(\bullet)$ is continuously differentiable and that the hazard rate $\mathrm{h}(\theta) /[1-\mathrm{H}(\theta)]$ is strictly increasing in $\theta$ (this guarantees a unique, well-behaved solution in the analysis). Let $\mathrm{c}>0$ denote D's court costs (a flat fee if trial occurs) but assume that P's attorney is compensated by a contingent fee, where $\alpha>0$ denotes the share of P's revenues (from settlement or from compensatory or punitive damages awards) which goes to compensate P's attorney. Finally, let $\mathrm{f}$ denote the fraction of punitive damages $\Delta$ which is allocated to $\mathrm{P}$.

Table 1 indicated that there were basically two types of allocation; Table 2 interprets these using the notation introduced above. We begin by examining the allocation rule which shares the punitive damages award between P and the State (as in Indiana and Oregon, listed as "Gross" in the 
Table), leaving P to pay his attorney from his share; we will show that the other most commonly used allocation rule, which shares the punitive damages award, net of the plaintiff's attorney's fee,

Place Table 2 about here

between P and the State (as in Alaska, Georgia, Missouri and Utah, listed in a sub-column under "Net"), results in exactly the same settlement bargaining subgame for P and D. Note that the essential difference between the allocation schemes used in these two sets of states concerns how the award is allocated between the State and the plaintiff's attorney; the plaintiff's payoff is the same under either the Gross or (non-Iowa) Net scheme. Iowa uses a variation on the Net scheme in which P's attorney is paid from the State's share; this acts to insulate $\mathrm{P}$ from his attorney's fees (on the punitive damages award) and to insulate his attorney from the split-award rate. Ignoring equilibrium considerations, the State receives the least under this scheme $($ since $(1-\alpha)(1-f) \Delta>(1-\alpha-f) \Delta)$. We will address the case of Iowa after characterizing equilibrium settlement negotiation under the more common schemes. Moreover, we ignore Illinois because it relies on judicial discretion in setting the State's share.

In addition, we employ notation for the litigants' strategies which differentiates the signaling model from the screening model. Wherever possible, upper case letters will be associated with the signaling analysis, while lower case letters will be used in the screening analysis. In particular, let $\mathrm{S}$ and s denote settlement offers in the signaling and screening games respectively; optimal offers will be denoted $S^{*}(\theta)$ and $s^{*}$, reflecting the fact that $D$ (who knows $\theta$ ) makes the offer $S^{*}(\theta)$ in the signaling game, while $\mathrm{P}$ (who does not know $\theta$ ) makes the offer $\mathrm{s}^{*}$ in the screening game. Let $\mathrm{R}(\mathrm{S}$ ) denote the probability that $\mathrm{P}$ rejects D's offer in the signaling game, and let $\mathrm{r}$ denote the probability 
that $\mathrm{D}$ rejects $\mathrm{P}$ 's offer in the screening game. In equilibrium, these will reduce to $\mathrm{R}^{*}(\theta)$ and $\mathrm{r}^{*}$, which provide the equilibrium probability of trial in the signaling and screening games, respectively. The Signaling Model

In the signaling version of the model, ${ }^{13}$ the privately informed $\mathrm{D}$ makes a settlement offer $\mathrm{S}$ to $\mathrm{P}$, who forms beliefs based on this offer (denoted $\mathrm{b}(\mathrm{S})$ ) about the true value of $\theta$. Thus $\mathrm{P}$ will accept an offer S if and only if:

$$
(1-\alpha) \mathrm{S} \geq(1-\alpha) \pi \delta+(1-\alpha) \pi \mathrm{b}(\mathrm{S}) \mathrm{f} \Delta .
$$

To see why, notice that if $\mathrm{P}$ settles for the amount $\mathrm{S}$, the share $\alpha$ is paid to P's attorney as a contingent fee. On the other hand, if $\mathrm{P}$ goes to trial, then (if $\mathrm{P}$ wins) $\mathrm{P}$ 's attorney receives a share $\alpha$ of the compensatory damages $\delta$ plus a share $\alpha$ of the punitive damages received by $\mathrm{P}$ (that is, $\mathrm{f} \Delta$ ); both terms are weighted by P's estimate of their respective likelihoods of occurring ( $\pi$ and $\pi \mathrm{b}(\mathrm{S})$, respectively). This leaves $\mathrm{P}$ with the share $1-\alpha$ of both $\delta$ and $\mathrm{f} \Delta$ (again, probabilistically weighted). Notice from Table 2 that this is true for both the Gross and (non-Iowa) Net allocation schemes. Thus, P's decision problem is the same under either allocation rule. Moreover, the contingent fee rate $\alpha$ is also irrelevant to P's choice between settlement and trial, because the contingent fee applies in either outcome. Thus $P$ accepts $S$ if and only if $S \geq \pi \delta+\pi b(S) f \Delta$.

The loss to D from settlement is simply $\mathrm{S}$, while the loss to $\mathrm{D}$ from trial depends on his type. At trial, the $\mathrm{D}$ of type $\theta$ expects to lose $\pi \delta+\pi \theta \Delta+\mathrm{c}$. P rejects the demand $\mathrm{S}$ with probability $R(S)$, which leads to trial, and accepts the offer $S$ with probability $1-R(S)$. Thus, the expected loss (EL) to a $\mathrm{D}$ of type $\theta$ who offers $\mathrm{S}$ to a $\mathrm{P}$, who rejects the offer with probability $\mathrm{R}(\mathrm{S})$, is:

$$
\operatorname{EL}(\mathrm{S}, \mathrm{R}(\mathrm{S}) ; \theta) \equiv(1-\mathrm{R}(\mathrm{S})) \mathrm{S}+\mathrm{R}(\mathrm{S})[\pi \delta+\pi \theta \Delta+\mathrm{c}] .
$$

Clearly, a D of type $\theta$ will choose $\mathrm{S}$ to minimize this expected loss. 
A revealing equilibrium consists of a settlement demand function $S^{*}(\theta)$, a probability of rejection function $R^{*}(S)$, and beliefs $b^{*}(S)$, such that: 1) each type of D is minimizing expected loss EL; 2) P's optimal rejection function maximizes his payoff (see the Appendix); and 3) P's beliefs b(S) about the type of $\mathrm{D}$ that would make the offer $\mathrm{S}$ are, in equilibrium, correct. By this last statement we mean that, in equilibrium, if a $\mathrm{D}$ of type $\theta$ makes an offer using the settlement demand function $S^{*}(\theta), P$ (upon seeing this offer) believes the type of $D$ making the offer is type $\theta$ (that is, $b^{*}\left(S^{*}(\theta)\right)$ $=\theta$ ). In the Appendix we provide a formal expression of these conditions and an abbreviated derivation of the unique revealing equilibrium for our signaling model. ${ }^{14}$ There it is shown that D's equilibrium settlement offer function is $S^{*}(\theta)=\pi \delta+\pi f \Delta \theta$. Substituting this into the plaintiff's equilibrium rejection function, $\mathrm{R} *(\mathrm{~S})$ (see the Appendix for details), yields P's equilibrium probability of trial function, which we denote as $\mathrm{R}^{*}(\theta)$, which is the probability that settlement breaks down and trial results (as a function of D's type): $R^{*}(\theta)=1-\{[\pi(1-f) \Delta \theta+c] /[\pi(1-f) \Delta+c]\}^{f /(1-f)}$. As long as $\mathrm{P}$ receives some portion of any punitive damages award he wins (i.e., as long as $\mathrm{f}>0$ ), the term in braces on the right is always a fraction, unless $\theta=1$. If $\theta=1$, the term in braces equals 1 , meaning that $\mathrm{R}^{*}(1)=0$ and thus $\mathrm{P}$ never rejects the demand associated with the type that will be found liable for punitive damages with certainty $(\theta=1)$; that type offers $\pi \delta+\pi \mathrm{f} \Delta$, which is always accepted. Lower offers result in a higher likelihood of rejection; the rate at which this likelihood of rejection increases with a decrease in the offer is just sufficient to make D reveal his type through his offer $\mathrm{S} *(\theta)$

\section{$\underline{\text { Signaling Model Comparative Statics }}$}

Thus the equilibrium settlement amount $S^{*}(\theta)$ is an increasing function of $\theta$ : types of $D$ who anticipate a higher likelihood of being found grossly negligent make higher settlement offers. In 
addition, $\mathrm{S}^{*}(\theta)$ is independent of $\mathrm{c}$ and $\alpha$, and is increasing in all of those elements that contribute to a higher expected gain to $\mathrm{P}$ from trial: that is, $\pi, \delta, \Delta$ and $\mathrm{f}$. The expression $\mathrm{R}^{*}(\theta)$ is independent of $\delta$ and $\alpha$, is decreasing in $\mathrm{c}$, and is increasing in $\pi, \Delta$ and $\mathrm{f}$. Thus, changes in the contingent fee rate $\alpha$ do not affect the equilibrium. Both the equilibrium settlement offer and likelihood of trial are increased by increases in the following: 1) the likelihood of being found liable for the harm, $\pi ; 2$ ) the anticipated amount of punitive damages to be paid if found liable for such an award, $\Delta$; and 3) the share of such an award, f, which P gets to keep. Increases in compensatory damages increase the equilibrium offer, while increases in D's court costs increase the likelihood of settlement.

\section{The Screening Model}

In the screening analysis,${ }^{15}$ the uninformed $\mathrm{P}$ makes a settlement offer $\mathrm{s}$ to the privately informed $\mathrm{D}$. The $\mathrm{D}$ of type $\theta$ accepts the offer $\mathrm{s}$ if and only if $\mathrm{s} \leq \pi \delta+\pi \theta \Delta+\mathrm{c}$, since this is his expected loss from going to trial. Thus, the "marginal type" of $\mathrm{D}$ is the value of $\theta$ just willing to accept $\mathrm{s}$; if we denote the equilibrium demand for $\mathrm{P}$ as $\mathrm{s}^{*}$, then the equilibrium marginal type is $\theta^{*}$ $=\left(\mathrm{s}^{*}-\pi \delta-\mathrm{c}\right) / \pi \Delta$. In equilibrium all types with liability assessments $\theta$ less than $\theta^{*}$ will reject the demand $\mathrm{s}^{*}$ and proceed to trial while all those with assessments $\theta$ greater than or equal to $\theta *$ will settle with P at s*. This motivates P's choice of demand: he adjusts $s$ to trade off the expected return from trial with the expected return from settlement.

Note that, if the case settles, then P receives $(1-\alpha) s^{*}$, with the remainder going to P's attorney. If the case goes to trial, then $P$ receives the share $(1-\alpha)$ of any compensatory damages or punitive damages awarded to $\mathrm{P}$, once again, weighted by the probability that $\mathrm{P}$ wins that award. As before, under the Net scheme, $\mathrm{P}$ would receive the share $\mathrm{f}$ of $(1-\alpha) \Delta$ (since the amount $\alpha \Delta$ represents P's attorney's fee for the punitive damages portion of the trial). Thus, P's payoff in the 
event of trial is the same under either allocation rule.

In the Appendix we provide a formal derivation of the equilibrium demand $\mathrm{s}^{*}$. There we show that the equilibrium marginal type $\theta *$ satisfies the following condition:

$$
\mathrm{h}(\theta *) /\left[1-\mathrm{H}\left(\theta^{*}\right)\right]=\pi \Delta /[\pi \theta *(1-\mathrm{f}) \Delta+\mathrm{c}] .
$$

Since the ratio on the left is assumed to be a strictly increasing function of $\theta$, and the ratio on the right is clearly a strictly decreasing function of $\theta$, there is a unique interior $\theta *$ (that is, a type $\theta *$ strictly between 0 and 1 that will solve the above equality) as long as $\mathrm{h}(0)<\pi \Delta / \mathrm{c}$; in this case, $\mathrm{P}$ 's optimal demand is $\mathrm{s}^{*}=\pi \delta+\pi \Delta \theta^{*}+\mathrm{c}$. High D-types settle at this amount while low D-types reject the demand and go to trial. If $h(0) \geq \pi \Delta / \mathrm{c}$, then there is no interior marginal type and $\mathrm{P}$ prefers to settle with all D types at $\mathrm{s}^{*}=\pi \delta+\mathrm{c}$; we continue under the assumption that the marginal type is interior.

\section{$\underline{\text { Screening Model Comparative Statics }}$}

For the case of an interior $\theta^{*}, \mathrm{~s}^{*}$ is independent of $\alpha$ and increasing in $\delta, \mathrm{f}$ (through $\left.\theta^{*}\right), \pi$ and $\Delta$ (both directly and indirectly through $\left.\theta^{*}\right) .{ }^{16}$ Increases in $\pi, \Delta$ and $\mathrm{f}$ result in an increase in the marginal type $\theta^{*}$, meaning that there is a greater chance that the offer will be rejected, since more types of $\mathrm{D}$ will lie below $\theta^{*}$; this makes the likelihood of trial, $\mathrm{r}^{*}$, increase since the equilibrium probability of trial for the screening version of the model is $\mathrm{r}^{*} \equiv \mathrm{H}\left(\theta^{*}\right)$. Thus, the equilibrium probability of trial is independent of $\alpha$ and $\delta$, decreasing in $\mathrm{c}$, and increasing in $\pi, \Delta$ and $\mathrm{f}$. In the screening model it is the uninformed plaintiff who is making the demand, so it is not possible for changes in D's type, $\theta$, to influence P's calculation of $\theta^{*}, \mathrm{r}^{*}$ or the demand P makes, $\mathrm{s}^{*}$.

\section{Signaling and Screening Results for the Iowa Case}

For the case of signaling, a settling P receives $(1-\alpha) S$ while expecting to receive $(1-\alpha) \pi \delta$ 
$+\pi \mathrm{b}(\mathrm{S}) \mathrm{f} \Delta$ from going to trial, yielding an inequality analogous to (1) above:

$$
(1-\alpha) \mathrm{S} \geq(1-\alpha) \pi \delta+\pi \mathrm{b}(\mathrm{S}) \mathrm{f} \Delta .
$$

Note that, if we replace $\mathrm{f}$ in (3) by $(1-\alpha) \hat{\mathrm{f}}$ we see that the inequalities (1) and (3) are of the same form. It can be shown that the resulting equilibrium probability of trial and the equilibrium settlement for the Iowa case have the same functional forms as $R^{*}(\theta)$ and $S^{*}(\theta)$ respectively, with the parameter freplaced by $\hat{f}=f /(1-\alpha)$. Thus the Iowa equilibrium functions share all the comparative static properties of those previously derived and are strictly increasing in $\alpha$ as well.

For the screening case, $\theta *$ is defined by an equation analogous to (2), with $\mathrm{f}$ replaced by $\hat{\mathrm{f}}=$ $\mathrm{f} /(1-\alpha)$, leading again to functions analogous to $\mathrm{r}^{*}$ and $\mathrm{s}^{*}$. This leads, once again, to the same comparative statics as in the earlier screening analysis with the added result that increases in $\alpha$ increase the equilibrium likelihood of trial and the equilibrium settlement.

Thus, under the Iowa scheme, a higher contingent fee leads to a higher probability of trial and higher settlements. This is because the State pays the entire attorney's fee for the punitive damages portion of the litigation $(\alpha \pi \theta \Delta$; see Table 2$)$ when a case goes to trial. Thus, the Iowa scheme effectively subsidizes trial relative to settlement. Moreover, since the equilibrium probability of trial and equilibrium settlement under the other allocation schemes are independent of $\alpha$, they coincide with those under the Iowa scheme only for $\alpha=0$ (since then $\hat{f}=f$ ). Thus, for given $f$, the equilibrium probability of trial and equilibrium settlement will be higher under Iowa's allocation scheme than under either the Gross or (non-Iowa) Net schemes.

Comparing the Signaling and Screening Results

Thus, with the exception of $\mathrm{c}$ and D's type, $\theta$, which affect $S^{*}(\theta)$ and $\mathrm{s}^{*}$ differently, ${ }^{17}$ the equilibrium settlement amounts $S^{*}(\theta)$ and $\mathrm{s}^{*}$ have the same comparative statics with respect to $\alpha$, 
$\delta, \pi, \Delta$ and f. Moreover, $\mathrm{R}^{*}(\theta)$ and $\mathrm{r}^{*}$ have the same comparative statics with respect to $\alpha, \mathrm{c}, \delta$, $\pi, \Delta$ and $\mathrm{f}$. Of particular interest is the impact of P's share of punitive damages $\mathrm{f}$ on the equilibrium amount and likelihood of settlement. Notice that (in both bargaining models) an increase in $\mathrm{f}$ results both in a higher settlement amount offered (or demanded) and a greater likelihood of trial. Alternatively put, an increase in the State's share (1 - f) of punitive damages results in more settlements at lower amounts. Thus, an increase in the State's share provides greater incentives for the parties to settle (and cut out the State) and provides a two-fold benefit to D, who goes to trial less often and settles for a lower amount. Unless punitive damages rise to restore deterrence, D's expected loss (which presumably motivates his investment in care to avoid the initial harm) is reduced by both effects. Finally, complete confiscation of punitive damages yields different predictions by the two models. In the signaling model, if $\mathrm{f}=0$ then settlement always occurs and $\mathrm{D}$ only offers the expected value of compensatory damages, $\pi \delta$, which $\mathrm{P}$ always accepts. Thus, any deterrent effect of punitive damages is completely eviscerated. In the screening model, the plaintiff demands more than the compensatory damages plus D's court costs (recall that $\mathrm{s}^{*}=\pi \delta+\pi \Delta \theta^{*}+\mathrm{c}$ ), so there are still trials in equilibrium (since $\theta^{*}>0$ ) even if $\mathrm{f}=0$.

\section{THE STATE'S CHOICE OF THE SPLIT-AWARD RATE}

How does the State decide on the appropriate value of $\mathrm{f}$, especially when it cannot predict whether the settlement bargaining subgame involves signaling, screening, or some intermediate outcome? The reason the State cannot predict the form of the settlement bargaining game is that (at least when $\mathrm{H}$ is the uniform distribution) $\mathrm{D}$ always prefers the signaling game while $\mathrm{P}$ always prefers the screening game. Therefore, the litigants will not generally agree on the bargaining game form. 
In order to deal with this problem, we assume a "random proposer" model ${ }^{18}$ for the settlement bargaining subgame, in which $\mathrm{D}$ makes the settlement offer with probability $\lambda$, and $\mathrm{P}$ makes the settlement offer with probability $1-\lambda$, with $0<\lambda<1$ some exogenously determined parameter that reflects the nature of the population of litigants. As a consequence, the expected equilibrium gain to $\mathrm{P}$ and loss to $\mathrm{D}$ for the game with a random proposer is a weighted average of their respective equilibrium payoffs in the signaling and screening games. Since the equilibrium payoffs of the signaling and screening games are very similar in their dependence on the parameters of the model, a weighted average of these payoffs will also behave in a similar manner.

It seems likely that many considerations could affect the choice of f; we focus on two that reflect the arguments made by proponents of such reform: deterrence reduction and revenue maximization. ${ }^{19}$ The former objective has been suggested as a basis for much of the existing tort reform: some reformers argue that manufacturers are over-deterred, investing too much on care or discontinuing products entirely so as to avoid the risk of unwarranted or excessive punitive damages awards. Alternatively, states may simply want a share of these awards, either based on the earlier argument about social compensation, or simply because this is one more source of revenue for state programs. As pointed out earlier, this may or may not be part of a first-best system of redistribution. However, from a positive perspective (or a second-best perspective), a punitive damages award presents a particularly attractive target for a legislature, since the defendant has been judged to be grossly negligent and thus deserves to pay while the plaintiff, having already received compensatory damages, arguably does not deserve to receive a windfall. On the other hand, to the degree that society has been harmed, the State is entitled to collect compensation on its behalf in the form of punitive damages. This view is consistent with the fact that the State does not claim a share of 
compensatory damages awards or pretrial settlements. Revenue maximization is therefore an alternative objective of interest. We examine the deterrence-reduction and the revenue-maximization objectives in turn and then reconsider the split-award statutes employed by the states.

One method for choosing f would be to construct an "optimal deterrence" model. ${ }^{20}$ We've already indicated that one stated goal of reformers supporting sharing statutes is to reduce deterrence, asserting that defendants are currently over-deterred. Presumably, D's level of care will be based on his ex ante expected loss. In the Appendix we show that D's ex ante expected total loss is increasing in $\mathrm{f}$ in the signaling case. In the screening case, a similar loss function can be constructed for $\mathrm{D}$; it is also increasing in $\mathrm{f}$. Thus, in both basic bargaining models (and therefore in the randomproposer model), an increase in f would increase D's incentives for care. Therefore, $\mathrm{f}$ could be manipulated to achieve various levels of care, depending upon the details of how care-taking investments are modeled.

As our main focus we consider the determination of $\mathrm{f}$ so as to maximize the State's gain from raising revenue via a split-award statute. If the Gross punitive damages allocation scheme is employed (see Table 2) wherein P's attorney is paid out of P's allocation (as in Indiana and Oregon), the State's Expected Gain if the settlement bargaining subgame involves signaling is given by SEG(f) $\equiv \int{ }_{0}^{1} R^{*}(\theta ; f) \pi \theta(1-f) \Delta h(\theta) d \theta$. The corresponding expected gain to the State if the settlement bargaining game involves screening is given by $\operatorname{seg}(\mathrm{f}) \equiv \int \pi \theta(1-\mathrm{f}) \Delta \mathrm{h}(\theta) \mathrm{d} \theta$, where the integral is on $\left[0, \theta^{*}(\mathrm{f})\right]$. The (non-Iowa) Net allocation scheme, wherein P's attorney is paid in full, after which the remaining punitive damages are shared (as in Alaska, Georgia, Missouri and Utah), results in expected gains to the State of $(1-\alpha) \operatorname{SEG}(f)$ and $(1-\alpha) \operatorname{seg}(f)$, respectively, under signaling and screening. Thus, the share which maximizes the State's expected gain (given signaling or screening) 
is also invariant to which of these two allocation rules is employed.

Due to mathematical complexity (of the signaling subcase), the share $f$ that maximizes the State's expected gain can only be found by assuming a specific distribution for $\theta$ and using computational methods. Thus, in what follows, we assume that $\theta$ is distributed uniformly; that is, $\mathrm{H}(\theta)=\theta$ on $[0,1]$; for notational convenience in the discussion and figures to follow, let $\mathrm{z}=\pi \Delta / \mathrm{c}$. This yields $\operatorname{SEG}(\mathrm{f})=\mathrm{cz}(1-\mathrm{f}) \int_{0}^{1} \theta \mathrm{R}^{*}(\theta ; \mathrm{f}) \mathrm{d} \theta$, and $\operatorname{seg}(\mathrm{f})=\mathrm{c}(\mathrm{z}-1)^{2}(1-\mathrm{f}) / 2 \mathrm{z}(2-\mathrm{f})^{2}$. Finally, the earlier assumption that $\mathrm{h}(0)<\pi \Delta / \mathrm{c}$ translates into the equivalent restriction that $\mathrm{z}>1$. In the figures to be displayed, we have used the normalization $\mathrm{c}=1$ to simplify the illustration. This is without loss of generality for the purposes of computing the optimal $f$.

First, consider the State's expected gain when the settlement bargaining subgame involves signaling. Note that the function $\operatorname{SEG}(\mathrm{f})$ is zero at $\mathrm{f}=0$ and at $\mathrm{f}=1$. If $\mathrm{f}=1$, by definition the State receives no share. If $\mathrm{f}=0$, the State receives all of the punitive damages awarded at trial; however, if $\mathrm{f}=0$ then all cases settle, and hence there are no punitive damages awarded at trial. Figure 1 illustrates the function SEG(f) for two representative values of $z$, namely $z=3$ and $z=10$; our

Place Figure 1 about here

simulations suggest that this shape (i.e., that $\mathrm{SEG}(\mathrm{f})$ is a concave, single-peaked function) appears to hold for all values of $\mathrm{z}>1$; again, we caution the reader that these are numerical results, not results derived using purely analytical techniques. The Figure also indicates the approximate location of the revenue-maximizing value of $f$ for the two values of $z$. More generally, our numerical experiments indicate that the optimal $\mathrm{f}$ increases with $\mathrm{z}$ (that is, with an increase in $\pi$ or $\Delta$ or a decrease in c), but always appears to lie in the interval $[.5, .6]$ for all values of $\mathrm{z}>1$. 
Next, consider the State's expected gain when the settlement bargaining subgame involves screening. The function $\operatorname{seg}(\mathrm{f})$ is a decreasing, concave function of $\mathrm{f}$, maximized at $\mathrm{f}=0$ for all $\mathrm{z}$; this follows from the form of $\operatorname{seg}(\mathrm{f})$ and thus, while it relies on the assumed distribution $\mathrm{H}$, it does not rely on numerical analysis. Figure 2 illustrates $\operatorname{seg}(\mathrm{f})$ for the same values of $\mathrm{z}$ used in Figure 1.

Place Figure 2 about here

Finally, the State's expected gain from the random proposer model is given by $\lambda \mathrm{SEG}(\mathrm{f})+$ $(1-\lambda) \operatorname{seg}(f)$. This function appears to be to be a concave, single-peaked, function of $\mathrm{f}$ for any given value of $\lambda$; two versions of it are displayed in Figure 3 for the case $\lambda=0.5$ (note that Figure 1 displays the case $\lambda=1$ while Figure 2 displays the case $\lambda=0$ ).

Place Figure 3 about here

Finally, Figure 4 illustrates how changes in the weighting of the signaling and screening models (that is, changes in the parameter $\lambda$ ) affect the computed value of $\mathrm{f}^{*}$. Three observations are worth making. First, for any given value of $\lambda, \mathrm{f}^{*}$ seems quite insensitive to changes in $\mathrm{z}$. Second,

Place Figure 4 about here

$\mathrm{f}^{*}$ is quite sensitive to changes in $\lambda$ when $\lambda<0.3$, but appears to be fairly insensitive to such changes when $\lambda \geq 0.5$. Thus, taking a large share of P's punitive damages award is only consistent with revenue maximization if there is a strong reason to believe that actual bargaining overwhelmingly resembles the screening model (rather than the signaling model). The optimal $\mathrm{f}$ for the symmetric random proposer model (that is, when $\lambda=0.5$ ) is extremely robust: $\mathrm{f}^{*}$ is in the interval $[0.45,0.55]$ 
for all $\mathrm{z}>1$ and therefore it varies little with changes in $\pi, \Delta$ and c; moreover, it is completely insensitive to changes in $\delta, \alpha$ and which of the two allocation rules we examined is used. The Iowa Case

It is straightforward to show that the random proposer model for the Iowa net allocation scheme yields expected state revenue of $\lambda(1-\alpha) \operatorname{SEG}(\hat{\mathrm{f}})+(1-\lambda)(1-\alpha) \operatorname{seg}(\hat{\mathrm{f}})$, where again, $\hat{\mathrm{f}}=\mathrm{f} /(1-$ $\alpha)$. Note that this has precisely the same form as the previous model used for the net-allocation states. Thus, $\hat{\mathrm{f}}^{*}=\mathrm{f}^{*}$, and is therefore also in the interval $[0.45,0.55]$. If we use the fairly traditional value for $\alpha$ of 0.33 (which was the contingent fee rate in the McCartt case cited earlier; see footnotes 1 and 2), then this implies an optimal plaintiff's share for Iowa in the interval [0.30, 0.37], yielding a range of rates for the State of Iowa's share in the interval $[0.63,0.70]$. Since Iowa's statute subsidizes trial relative to settlement, the State can take a larger share of punitive damages without excessively encouraging settlement. Indeed, both Net schemes, despite their different implications for fixed f, yield the same expected revenue for the states and the same payoffs for the litigants and their attorneys, when the states' respective revenue-maximizing values of $f$ are used.

\section{IMPLICATIONS OF THE ANALYSIS}

\section{Equilibrium Settlement Bargaining and the Impact of Split-Award Statutes on Filings}

Although we have held filings fixed in order to focus on incentives to settle and cut out the State, we can also compare the cases filed under the Gross and Net statutes, respectively, with those that would be filed absent a split-award statute. While some cases might not be filed (due to a negative expected return for a plaintiff's attorney), once a case is filed it is always credible for $\mathrm{P}$ to go to trial because P's attorney (PA) pays the trial cost and P pays his attorney only if he wins. 
The impact of split-award statutes on PA's equilibrium payoff is complex. Although it is easy to show that a Gross scheme yields a lower equilibrium payoff for PA than does a (non-Iowa) Net scheme (for fixed f), it is not clear that PA's payoff is always lower under a split-award statute than without one. This is because, although an increase in f increases PA's payoff upon settlement under all allocation schemes (and upon trial as well in the Gross scheme), the plaintiff wants to go to trial more often under all allocation schemes when $\mathrm{f}$ is higher, and the attorney pays the trial cost. Thus, a split-award statute can better align P's and PA's incentives, especially where they are most at odds, in low-value cases.

At their respective State revenue-maximizing values of $\mathrm{f}$ (i.e., 0.5 for non-Iowa and 0.33 for Iowa), both Net allocation schemes give PA the same expected payoff, which is higher than under the Gross allocation scheme. Moreover, if : 1) $\theta$ is distributed uniformly; 2) the trial costs, c, are the same for both litigants; 3 ) the bargaining subgame follows the symmetric random proposer model; 4) PA's contingent fee rate is $\alpha=.33$ and 5) P's share is $\mathrm{f}=0.5$, then it can be shown that PA prefers the Gross allocation scheme to no statute for "small" cases (wherein $\mathrm{z}=\pi \Delta / \mathrm{c}$ is small), but not for large cases. Moreover, while there is a range of (low) z-values for which PA would refuse a case absent a split-award statute, this range is $\underline{\text { reduced under the Gross allocation scheme, and eliminated }}$ under the Net allocation scheme. Simply put, under the assumptions specified above, we find the surprising result that split-award statutes do not deter filings; indeed, they encourage the filing of some additional low-z cases. Again, this is because although PA receives a smaller share of settlements and (under the Gross scheme) awards, he does not incur the trial cost as often, because his client is more willing to settle, when $\mathrm{f}$ is lower (see the Appendix).

Figure 5 illustrates this result. The vertical axis indicates the payoff to PA, net of the expected 
contingent fee for the compensatory damages, where (for convenience) the cost of trial has been normalized to $\mathrm{c}=1$. We call this "PA's expected punitive payoff." Four payoff curves are drawn. The curve labeled "No Statute" indicates PA's expected punitive payoff when no split-award statute is present (i.e., for $\mathrm{f}=1$ ). Note that it dips below the axis when $\mathrm{z}$ is "small." In this region, since $\mathrm{z}$ $=\pi \Delta / \mathrm{c}$, this is likely to reflect cases which are weak either because $\pi$ (the likelihood of

Place Figure 5 about here

finding $\mathrm{D}$ liable at all) is low or because the case may be good but the ratio $\Delta / \mathrm{c}$ is low. Thus, when the curve dips below the axis, this represents levels of $\mathrm{z}$ (cases) that PA is going to decline to take, at least for low levels of expected compensatory damages.

The other curves reflect $f<1$. For example, the curves "Net, $f=0.5$ " and "Gross, $f=0.5$ " reflect the different allocation schemes, employing $\mathrm{f}=0.5$. Thus, PA will decline a much smaller set of cases under the Gross allocation scheme, and has no reason to decline any cases under the Net scheme. This means that, operated at $\mathrm{f}=0.5$, the split-award statute provides little or no disincentive for bringing cases and even encourages weak cases to be filed that might not have been filed absent the statute. One final curve is computed, that for "Gross, $f=0.25$," as in Indiana. Again, we find that a split-award statute using a Gross allocation scheme does not deter filings, but actually encourages the filing of low-z cases that would not be filed in the absence of a split-award statute. Since the Net allocation scheme always provides a higher expected payoff to the plaintiff's attorney, this result is true a fortiori for a split-award statute using a Net allocation scheme with $\mathrm{f}=0.25$, such as Georgia's. Thus, we find little evidence to suggest that such statutes reduce the incentives of attorneys to file, whatever the allocation scheme used. 


\section{$\underline{\text { Inferring States' Motives }}$}

Earlier we indicated two motivations for split-award statutes: deterrence reduction and revenue maximization. As we have seen, in the symmetric random proposer model, split-award statutes need not deter filings and hence need not contribute to reducing deterrence except by promoting settlement. For the same reasons, split-award statutes need not reduce litigation expenditures (which is one possible notion of how to "improve the business climate," a goal enunciated by Georgia). If $\mathrm{f}=1$ provides over-deterrence, then reducing $\mathrm{f}$ at first improves both deterrence and expected state revenues; however, when $\mathrm{f}$ gets lower than $\mathrm{f}^{*}$, further reductions in deterrence come at the expense of expected state revenues.

Indiana uses $f=0.25$ (that is, a state's share of $75 \%$; see Table 1 ), which is substantially outside the predicted range for revenue-maximization of $[0.45,0.55]$; moreover, Indiana caps the allowable punitive damages award. This suggests that Indiana primarily aims to reduce deterrence (though some revenue will be raised as a secondary consequence). At the other extreme, Alaska, Missouri, Utah and Iowa (approximately) use a revenue-maximizing rate for f; of these only Alaska employs caps on punitive damages awards, and these are less restrictive than Indiana's. Alaska, Missouri and Utah use an f-value in the predicted interval for revenue maximization. Iowa's $25 \%$ plaintiff share is slightly low when compared with the predicted range for f of $[0.30,0.37]$. However, 0.25 is fairly close to the computed optimum range and Iowa's plaintiff's share should be lower than that of the other net-allocation states according to the theory above, so it is in the predicted direction. Thus, deterrence reduction does not seem to be the primary objective of Alaska, Iowa, Missouri and Utah (though deterrence will be reduced somewhat when $\mathrm{f}<1$ ). ${ }^{21}$ Interestingly, Georgia, which has indicated that one basis for their split-award statute was revenue production (see McBride v. General 
Motors Corporation, 737 F.Supp 1563 (M.D. Ga. 1990)), uses too low a value of f (0.25). However, given this indicated basis for their statute, their employment of the Net scheme (which most encourages filings) and the fact that they do not use caps, we classify Georgia as being primarily revenue-driven. Oregon seems to fit someplace in between these two groups: it uses a Gross procedure and restricts the attorney's fee with respect to a punitive damages award, but it does not employ caps. On the other hand, Oregon's f is slightly too low to be considered an obvious revenue $\operatorname{maximizer}(f=0.40)$.

\section{SUMMARY AND CONCLUSIONS}

Using both signaling and screening models of settlement negotiations as incomplete information bargaining games, we developed an analysis of the revenue that split-award statutes could generate, conditioned on the allocation of a punitive damages award between the plaintiff, his attorney and the State. We found that split-award statutes simultaneously lower equilibrium settlement amounts and the likelihood of trial, as both parties act to cut out the State. We then modeled how the State might choose the plaintiff's share $f$, focusing mainly on the objective of revenue maximization for the State. In the signaling case, a purely confiscatory policy leads to no revenue, since all cases settle; the results are less extreme in the screening case where there are still some trials in equilibrium. We found that for a symmetric random proposer model, the revenuemaximizing plaintiff's share is approximately 50\% (33\% for Iowa) and is robust to variations in economic parameters and to whether the State's share is gross or net of the plaintiff's attorney's fee.

While one might expect that such a reform would act to suppress filings by plaintiffs' attorneys, we found that cases that are not profitable to an attorney can become profitable (even when 
sharing rates inconsistent with revenue maximization are employed). This is because sharing encourages the plaintiff to settle more often, allowing the plaintiff's attorney to save on trial costs. Further, these case are best characterized as being weak, in terms of either the size of the likely punitive damages award relative to the cost of trial or in terms of the likelihood the defendant will be found liable.

Finally, we used our results (along with information about other reforms that have been implemented) to infer the likely motivation in passing a split-award statute for the seven states of interest. We found that Oregon and (especially) Indiana appear to be motivated primarily by deterrence reduction while Alaska, Georgia, Iowa, Utah and (especially) Missouri seem to be motivated primarily by revenue generation. Of course, most of the states have not implemented such split-award statutes, even though sharing punitive damages awards would appear to be a ready source of revenue and can be justified as social compensation. This suggests that either we should observe more states adopting this reform in the future or, if not, that non-adopting states are more concerned with the reduction in deterrence that would accompany a split-award statute than with the revenue that could thereby be raised. 


\section{APPENDIX}

This analysis is for the Gross and non-Iowa Net allocation schemes. Similar results can be found for the Iowa case by substituting $\hat{f}=f /(1-\alpha)$ for $f$ in the equations.

The Signaling Model ${ }^{22}$

The equilibrium conditions are to find $S^{*}(\theta), R^{*}(S)$ and $b^{*}(S)$ such that:

1) $S^{*}(\theta)$ minimizes $\operatorname{EL}\left(S ; R^{*}(S) ; \theta\right)$;

2) $\mathrm{R}^{*}(\mathrm{~S})=1$ if $\mathrm{S}>\pi \delta+\pi \mathrm{b}^{*}(\mathrm{~S}) \mathrm{f} \Delta, \mathrm{R}^{*}(\mathrm{~S})=0$ if $\mathrm{S}<\pi \delta+\pi \mathrm{b}^{*}(\mathrm{~S}) \mathrm{f} \Delta$, and $\mathrm{R}^{*}(\mathrm{~S}) \in[0,1]$ if $\mathrm{S}=\pi \delta+\pi \mathrm{b}^{*}(\mathrm{~S}) \mathrm{f} \Delta$; and

3) $b^{*}\left(S^{*}(\theta)\right)=\theta$.

To minimize $\operatorname{EL}(\mathrm{S}, \mathrm{R}(\mathrm{S}) ; \theta)$, D's offer $\mathrm{S}^{*}(\theta)$ must satisfy the first-order condition:

$$
1-\mathrm{R}^{*}\left(\mathrm{~S}^{*}\right)+\mathrm{R}^{*}\left(\mathrm{~S}^{*}\right)\left[\pi \delta+\pi \theta \Delta+\mathrm{c}-\mathrm{S}^{*}\right]=0 .
$$

To permit interior values of $\mathrm{R}^{*}$ and to satisfy consistency of beliefs (item (3) above), it must be that $\mathrm{S}^{*}(\theta)=\pi \delta+\pi \theta \mathrm{f} \Delta$. Substituting $\pi \theta \Delta=\left[\mathrm{S}^{*}(\theta)-\pi \delta\right] / \mathrm{f}$ into equation (A1) yields:

$$
1-\mathrm{R}^{*}\left(\mathrm{~S}^{*}\right)+\mathrm{R}^{* \prime}\left(\mathrm{S}^{*}\right)\left[\left(\mathrm{S}^{*}-\pi \delta-\mathrm{c}\right)(1-\mathrm{f})+\mathrm{c}\right] / \mathrm{f}=0,
$$

where the dependence of $S^{*}$ on $\theta$ has been suppressed to call attention to the fact that equation (A2) is an ordinary differential equation which can be solved for the function $\mathrm{R}^{*}(\mathrm{~S})$. Note that the highest equilibrium demand will be $\bar{S}=\pi \delta+\pi \mathrm{f} \Delta$, while the lowest will be $\underline{S}=\pi \delta$. The highest equilibrium demand must be accepted with certainty, resulting in the boundary condition $R^{*}(\overline{\mathrm{S}})=0$. Solving equation (A2) with this boundary condition yields P's equilibrium strategy:

$$
\left.\left.R^{*}(S)=1-\{[S-\pi \delta-c)(1-f)+c] /[\bar{S}-\pi \delta-c)(1-f)+c\right]\right\}^{f /(1-f)}
$$


Combining this with D's equilibrium strategy $\mathrm{S}^{*}(\theta)=\pi \delta+\pi \theta \mathrm{f} \Delta$ yields (with some abuse of notation):

$$
\mathrm{R}^{*}(\theta) \equiv \mathrm{R}^{*}\left(\mathrm{~S}^{*}(\theta)\right)=1-\{[\pi \theta(1-\mathrm{f}) \Delta+\mathrm{c}] /[\pi(1-\mathrm{f}) \Delta+\mathrm{c}]\}^{\mathrm{f} /(1-\mathrm{f})} .
$$

The Screening Model

$\mathrm{P}$ chooses a settlement offer s so as to maximize his expected gain

$$
\int(1-\alpha)(\pi \delta+\pi \theta \mathrm{f} \Delta) \mathrm{dH}(\theta)+(1-\alpha)(1-\mathrm{H}(\tilde{\theta}(\mathrm{s})) \mathrm{s},
$$

where the integral is taken over the interval $[0, \tilde{\theta}(\mathrm{s})]$ and where $\theta(\mathrm{s})=(\mathrm{s}-\pi \delta-\mathrm{c}) / \pi \Delta$ is the marginal type of $\mathrm{D}$ who is just willing to accept the demand s. Notice that (again) the expression $1-\alpha$ can be factored out, and thus does not affect the settlement bargaining subgame. If $\mathrm{P}$ settles with some D types and goes to trial against others, then P's optimal offer $\mathrm{s}^{*}$ satisfies the following first-order condition:

$$
\left[\pi \delta+\pi \tilde{\theta}\left(\mathrm{s}^{*}\right) \mathrm{f} \Delta-\mathrm{s}^{*}\right] \mathrm{h}\left(\tilde{\theta}\left(\mathrm{s}^{*}\right)\right) \tilde{\theta}^{\prime}\left(\mathrm{s}^{*}\right)+1-\mathrm{H}\left(\tilde{\theta}\left(\mathrm{s}^{*}\right)\right)=0 .
$$

Substituting $\tilde{\theta}^{\prime}\left(\mathrm{s}^{*}\right)=1 / \pi \Delta$ and $\mathrm{s}^{*}=\pi \delta+\pi \Delta \tilde{\theta}\left(\mathrm{s}^{*}\right)+\mathrm{c}$, defining $\theta^{*} \equiv \tilde{\theta}\left(\mathrm{s}^{*}\right)$, and re-arranging yields $\mathrm{h}\left(\theta^{*}\right) /\left[1-\mathrm{H}\left(\theta^{*}\right)\right]=\pi \Delta /[\pi \theta *(1-\mathrm{f}) \Delta+\mathrm{c}]$.

The Impact of $\mathrm{f}$ on D's Ex Ante Expected Loss

In the signaling case, D's ex ante expected loss is:

$$
\int_{0}^{1}\left\{\left(1-R^{*}(\theta ; f)\right) S *(\theta ; f)+R *(\theta ; f)[\pi \delta+\pi \theta \Delta+c]\right\} h(\theta) d \theta .
$$

The term in braces $(\{\})$ is increasing in $\mathrm{f}$ for each $\theta$ since its derivative is:

$$
(\partial \mathrm{R} *(\theta ; \mathrm{f}) / \partial \mathrm{f})\left(-\mathrm{S}^{*}(\theta ; \mathrm{f})+[\pi \delta+\pi \theta \Delta+\mathrm{c}]\right)+\left(1-\mathrm{R}^{*}(\theta ; \mathrm{f})\right)(\partial \mathrm{S} *(\theta ; \mathrm{f}) / \partial \mathrm{f}) .
$$

The expressions $\left(\partial \mathrm{R}^{*}(\theta ; \mathrm{f}) / \partial \mathrm{f}\right),\left(-\mathrm{S}^{*}(\theta ; \mathrm{f})+[\pi \delta+\pi \theta \Delta+\mathrm{c}]\right),\left(1-\mathrm{R}^{*}(\theta ; \mathrm{f})\right)$ and $\left(\partial \mathrm{S}^{*}(\theta ; \mathrm{f}) / \partial \mathrm{f}\right)$ are all positive, yielding the desired result. 
In the screening case, D's ex ante expected loss is:

$$
\int(\pi \delta+\pi \Delta \theta+c) h(\theta) \mathrm{d} \theta+\left(\pi \delta+\pi \Delta \theta^{*}+\mathrm{c}\right)\left(1-\mathrm{H}\left(\theta^{*}\right)\right),
$$

where the integral is taken over $\left[0, \theta^{*}\right]$. The derivative of this expression with respect to $f$ reduces to $\pi \Delta(\partial \theta * / \partial f)\left(1-\mathrm{H}\left(\theta^{*}\right)\right)$, which is positive.

\section{Plaintiff's Attorney's Payoffs}

In the symmetric random proposer model under the Gross allocation scheme, let $\Pi^{\mathrm{PA}}$ be the payoff to the plaintiff's attorney under a contingent fee rate of $\alpha$ and a sharing rate of $f$. Then (unless otherwise indicated, all integrals are over $[0, \theta *])$ :

$$
\begin{aligned}
\Pi^{\mathrm{PA}}= & 1 / 2\left\{\int_{0}^{1}\left[\alpha(\pi \delta+\pi \mathrm{f} \theta \Delta)-\mathrm{cR}^{*}(\theta ; \mathrm{f})\right] \mathrm{h}(\theta) \mathrm{d} \theta\right\} \\
& +1 / 2\left\{\int[\alpha(\pi \delta+\pi \Delta \mathrm{f} \theta)-\mathrm{c}] \mathrm{h}(\theta) \mathrm{d} \theta+\alpha\left(\pi \delta+\pi \Delta \theta^{*}+\mathrm{c}\right)\left(1-\mathrm{H}\left(\theta^{*}\right)\right)\right\},
\end{aligned}
$$

where the first term in braces reflects signaling behavior, while the second term in braces reflects screening behavior. Thus (recall $\mathrm{z}=\pi \Delta / \mathrm{c}$ ):

$$
\begin{aligned}
\left(\Pi^{\mathrm{PA}}-\alpha \pi \delta\right) / \mathrm{c}=1 / 2\left\{\int_{0}^{1}\left[\alpha \mathrm{zf} \theta-\mathrm{R}^{*}(\theta ; \mathrm{f})\right] \mathrm{h}(\theta) \mathrm{d} \theta\right\} \\
\\
+1 / 2\left\{\int[\alpha \mathrm{zf} \theta-1] \mathrm{h}(\theta) \mathrm{d} \theta+\alpha\left(\mathrm{z} \theta^{*}+1\right)\left(1-\mathrm{H}\left(\theta^{*}\right)\right)\right\} .
\end{aligned}
$$

This term was referred to as "PA's expected punitive payoff" in Section 5 and in Figure 5. A similar expression can be constructed for the Net scheme. 


\section{FOOTNOTES}

1. McCartt v. Cantebury Inn, 52879 (District Court, Johnson County, Iowa, 1992). The award at trial was $\$ 300,000$ for compensatory damages and $\$ 4$ million in punitive damages. The following description of this case is quoted from the plaintiffs' attorney, Tom Riley of Cedar Rapids, IA in Blum (1992).

2. Iowa Code, §668A.1, first adopted in 1987. Only if the jury finds that the conduct of the defendant was directed specifically at the plaintiff will the State's share be zero. In the example at hand, after the trial, the plaintiffs negotiated a $\$ 1$ million settlement which allotted $\$ 300,000$ to cover the compensatory damages award made at trial. Of the remaining $\$ 700,000, \$ 175,000$ (25\%) went to the plaintiff as punitive damages, $\$ 233,333.33$ went to cover plaintiff's attorney fees and the residual $(\$ 291,666.67)$ went to the State.

3. For example, see Daughety and Reinganum (1997, 1998), Eisenberg (1998), Eisenberg, et. al. (1997), Ellis (1982), Galanter and Luban (1993), Hylton (1998), Luban (1998), Moller, et. al. (1999), Owen (1976, 1994), Polinsky (1997), Polinsky and Shavell (1998), Rustad (1992), and Viscusi (1998a,b). In particular, Rustad argues that there is a widespread (but erroneous) perception among policy makers and the public that punitive damages are excessive and hurt competition.

4. See Breslo (1992), Dodson (2000), Klaben (1994), Kirgis (1993), and Sloane (1993) for discussions of the social compensation argument and some associated constitutional issues for splitaward statutes.

5. Chief Justice Rehnquist suggested complete confiscation of the award in his dissent in Smith $v$. Wade,103 S. Ct. 1625 (1982) at 1641: "Punitive damages are generally seen as a windfall to plaintiffs, who are entitled to receive full compensation for their injuries -- but no more. Even assuming that a punitive 'fine' should be imposed after a civil trial, the penalty should go to the State, not to the plaintiff -- who by hypothesis is fully compensated."

6. See the list of states in the Appendix in Justice Ginsburg's dissent in BMW of North America, Inc. v. Ira Gore, Jr., 116 S. Ct. 1589 (1996) at 1619, which also listed Florida and Kansas (these latter two have since expired). New York's split-award statute expired in 1994; Colorado's Supreme Court found its statute unconstitutional. Alaska's split-award statute was passed in 1997. Thus, approximately $25 \%$ of the states have, or have had, such statutes.

7. The State may also monitor the process. In Iowa, for example, staff in the Attorney General's Office file appearances to protect the State's interest in punitive damages cases. They also advise litigants in post-trial bargaining negotiations.

8. Courts in Florida, Georgia and Iowa have upheld split-award statutes against uncompensated takings challenges while Colorado's Supreme Court found that statute to effect such a taking. Given

that the State receives some of the punitive damages award under a split-award statute, some 
defendants have argued that such awards constitute excessive fines (for details, see Klaben, 1994, pp. 141-7) and should be subject to limitations under the Excessive Fines Clause. Excessive fines arguments have been raised in cases in Georgia, Iowa and Oregon.

9. Polinsky and Shavell (1998) briefly mention split-award statutes and suggest that filings would be reduced; they do not consider the impact of split-award statutes on settlement. As we will see in Section 5 below, our equilibrium analysis indicates that split-award statutes, in conjunction with contingent-fee compensation, can actually encourage plaintiffs' attorneys to pursue weak cases, largely because of their impact on settlements.

10. For a discussion of modeling issues associated with inconsistent priors models and an explication of "consistent priors" models (i.e., asymmetric information games), see Daughety (2000). As is discussed there, and as Binmore (1992) demonstrates, the use of an inconsistent priors model conflicts with a maintained hypothesis of fully rational behavior by the litigants.

11. Wang, Kim and Yi (1994) discuss some conditions under which specific infinite-horizon bargaining games effectively reduce to ultimatum games.

12. Juries might adjust $\Delta$ if they knew about the statute (we take $\Delta$ as fixed). This information is supposed to be kept from juries to avoid obvious incentive problems, as they are citizens of the states that would receive the share of the award. In Burke v. Deere \& Co., 780 F. Supp. 1225 (S.D. Iowa 1991), the plaintiff's attorney informed the jury of the split-award statute and encouraged it to increase the punitive damages award; this contributed to the Eighth Circuit throwing out the award. Oregon and Georgia have viewed this as "harmful error." We do not know if citizens generally are aware of such statutes.

13. This is a fairly direct extension of the signaling model in Reinganum and Wilde (1986), though it is an extension due to the use of contingent fees and the split-award statute.

14. Our bargaining analysis holds filings fixed; we examine the effect of split-award statutes on filings in Section 5.

15. Again, while this is a fairly direct extension of the screening model in Bebchuk (1984), it is an extension since we are considering contingent fees and the split-award statute.

16. One would expect $\mathrm{s}^{*}$ to be increasing in c. While this seems intuitive, and this result can be shown if $\theta$ is uniformly distributed, we've not been able to show this for general distributions $\mathrm{H}$. This is because $\mathrm{c}$ affects $\mathrm{s}^{*}$ directly (positively) as well as indirectly through $\theta^{*}$ (negatively).

17. With respect to $c$, this is because the shift in bargaining power in moving from signaling to screening enables $\mathrm{P}$ to extract $\mathrm{c}$ from $\mathrm{D}$. With respect to $\theta$, this is because the shift in bargaining power also means that the uniformed player moves first rather than second. 
18. Random proposer models have been used extensively in bargaining models; see, for example, Binmore and Herrero (1988), Rubinstein and Wolinsky (1985), and Wolinsky (1987).

19. Admittedly, there may be a number of motives for states to have split-award statutes. Sloane (1993), footnote 92, observes that the legislative history for Florida's statute explicitly stated the goal of deterring plaintiffs from pursuing punitive damages cases. In McBride v. General Motors Corporation, 737 F.Supp 1563 (M.D. Ga.1990), the State of Georgia specifically included revenue raising as well as improving the business climate in the state as reasons for their statute.

20. In what follows we now highlight the role of $\mathrm{f}$ as appropriate. Thus, for example, we let $\mathrm{R} *(\theta ; \mathrm{f})$ be the equilibrium probability of trial for a $\mathrm{D}$ of type $\theta$ in the signaling analysis. For the case of Iowa, this is $\mathrm{R}^{*}(\theta ; \hat{\mathrm{f}})$, where $\hat{\mathrm{f}}=\mathrm{f} /(1-\alpha)$. Similarly, we extend the notation for the other equilibrium functions to be $S^{*}(\theta ; f), S^{*}(\theta ; \hat{f}), r^{*}(\mathrm{f}), r^{*}(\hat{\mathrm{f}}), \mathrm{s}^{*}(\mathrm{f})$ and $\mathrm{s}^{*}(\hat{\mathrm{f}})$ as appropriate.

21. Utah's statute was enacted while a very large lawsuit involving punitive damages was pending. Unfortunately for Utah, but consistent with the incentives provided by such a statute, the case subsequently settled (private communication with a member of Utah's Division of Finance).

22. For formal proofs regarding the existence and uniqueness of revealing equilibria (and the elimination of pooling equilibria) in similar signaling games, see Reinganum and Wilde (1986). 


\section{REFERENCES}

Bebchuk, Lucian A. 1984. "Litigation and Settlement Under Imperfect Information," 15 Rand Journal of Economics 404-15.

Binmore, Ken. 1992. Fun and Games: A Text on Game Theory. Lexington, MA: D. C. Heath and Company.

Studies 33-48.

and Maria J. Herrero. 1988. "Security Equilibrium," 55 Review of Economic

Blum, Andrew. 1992. "Peeping Toms Lose Out in Court.” National Law Journal, September 14.

Breslo, James A. 1992. "Taking the Punitive Damage Windfall Away From the Plaintiff: An Analysis," 86 Northwestern University Law Review 1130-68.

Cooter, Robert D. 1989. "Punitive Damages for Deterrence: When and How Much?," 40 Alabama Law Review 1143-96.

Daughety, Andrew F. 2000. "Settlement," in B. Bouckaert and G. DeGeest, eds., Encyclopedia of Law and Economics, Volume 5. Cheltenham, UK: Edward Elgar Publishing Co.

and Jennifer F. Reinganum. 1997. "Everybody Out of the Pool: Products

Liability, Punitive Damages and Competition," 13 Journal of Law, Economics and Organization 41032.

and 1998. "A Note on Multiple Equilibria and Punitive

Damages Rules in 'Everybody Out of the Pool'," 14 Journal of Law, Economics and Organization 379-87.

Dodson, Scott. 2000. "Note: Assessing the Practicality and Constitutionality of Alaska's SplitRecovery Punitive Damages Statute," 49 Duke Law Journal 1335-69.

Eisenberg, Theodore. 1998. "Measuring the Deterrent Effect of Punitive Damages," 87 Georgetown Law Journal 347-58.

, John Goerdt, Brian Ostrom, David Rottman and Martin T. Wells. 1997. "The Predictability of Punitive Damages," 26 The Journal of Legal Studies 623-62.

Ellis, Dorsey D. 1982. "Fairness and Efficiency in the Law of Punitive Damages," 56 Southern California Law Review 1-132.

Galanter, Marc and David Luban. 1993. "Poetic Justice: Punitive Damages and Legal Pluralism," 
42 American University Law Review 1393-1463.

Hylton, Keith N. 1998. "Punitive Damages and the Economic Theory of Penalties," 87 Georgetown Law Journal 421-472.

Kahan, Marcel and Bruce Tuckman. 1995. "Special Levies on Punitive Damages: Decoupling, Agency Problems and Litigation Expenditures," 15 International Review of Law and Economics 17585 .

Kaplow, Louis and Steven Shavell. 1994. "Why the Legal System is Less Efficient than the Income Tax in Redistributing Income," 23 Journal of Legal Studies 667-81.

Kirgis, Paul F. 1993. "The Constitutionality of State Allocation of Punitive Damage Awards," 50 Washington and Lee Law Review 843-75.

Klaben, Matthew J. 1994. "Note: Split-Recovery Statutes: The Interplay of the Takings and Excessive Fines Clauses," 80 Cornell Law Review 104-57.

Luban, David. 1998. "A Flawed Case Against Punitive Damages," 87 Georgetown Law Journal 35980 .

Moller, Erik, Nicholas M. Pace and Stephan J. Carroll. 1999. "Punitive Damages in Financial Injury Jury Verdicts," 28 The Journal of Legal Studies 283-340.

Owen, David G. 1976. "Punitive Damages in Products Liability Litigation," 74 Michigan Law Review 1257-1372.

. 1994. "A Punitive Damages Overview: Functions, Problems and Reform," 39 Villanova Law Review 363-413.

Polinsky, A. Mitchell. 1997. "Are Punitive Damages Really Insignificant, Predictable, and Rational? A Comment on Eisenberg et al.," 26 The Journal of Legal Studies 663-77.

and Yeon-Koo Che. 1991. "Decoupling Liability: Optimal Incentives for Care and Litigation," 22 RAND Journal of Economics 562-70.

and Steven Shavell. 1998. "Punitive Damages: An Economic Analysis," 111

Harvard Law Review 869-962.

Reinganum, Jennifer F. and Louis L. Wilde. 1986. "Settlement, Litigation, and the Allocation of Litigation Costs," 17 RAND Journal of Economics 557-66.

Rubinstein, Ariel and Asher Wolinsky. 1985. "Equilibrium in a Market with Sequential Bargaining," 
53 Econometrica 1133-50.

Rustad, Michael. 1992. "In Defense of Punitive Damages in Products Liability: Testing Tort Anecdotes with Empirical Data," 78 Iowa Law Review 1-88.

Sanchirico, Chris William. 2000. “Taxes versus Legal Rules as Instruments for Equity: A More Equitable View," 29 Journal of Legal Studies 797-820.

Sloane, Lynda A. 1993. "The Split Award Statute: A Move Toward Effectuating the True Purpose of Punitive Damages," 28 Valparaiso University Law Review 473-512.

Sunstein, Cass R., Daniel Kahneman and David Schkade. 1998. "Assessing Punitive Damages (with Notes on Cognition and Valuation in Law,” 107 Yale Law Journal 2071-2154.

Viscusi, W. Kip. 1998a. "The Social Costs of Punitive Damages Against Corporations in Environmental and Safety Torts," 87 Georgetown Law Journal 285-346. . 1998b. "Why There is No Defense of Punitive Damages," 87 Georgetown Law

Journal 381-96.

Wang, Gyu Ho, Jeong Yoo Kim and Jong Goo Yi. 1994. "Litigation and Pretrial Negotiation under Incomplete Information," 10 Journal of Law, Economics and Organization 187-200.

Wolinsky, Asher. 1987. "Matching, Search and Bargaining,” 42 Journal of Economic Theory 311-33. 
Table 1: Split-Award Statute Provisions

\begin{tabular}{|l|c|c|c|}
\hline \multicolumn{1}{|c|}{ State } & State's $\%$ & $\begin{array}{c}\text { Allocation Net of } \\
\text { Attorney Fees? }\end{array}$ & Destination for Funds \\
\hline Alaska & 50 & Yes & Treasury \\
\hline Georgia $^{1}$ & 75 & Yes & Treasury \\
\hline Illinois $^{2}$ & \multicolumn{2}{|c|}{ Judge's discretion } & Dept. of Human Svcs. \\
\hline Indiana & 75 & No & $\begin{array}{c}\text { Violent Crime Victims } \\
\text { Compensation Fund }\end{array}$ \\
\hline Iowa & 75 & Yes & $\begin{array}{c}\text { Civil Reparations } \\
\text { Trust Fund }\end{array}$ \\
\hline Missouri & 50 & Yes & $\begin{array}{c}\text { Tort Victim's } \\
\text { Compensation Fund }\end{array}$ \\
\hline Oregon $^{3}$ & 60 & No & $\begin{array}{c}\text { Criminal Injuries } \\
\text { Compensation Account }\end{array}$ \\
\hline Utah $^{5}$ & 50 & Yes & Treasury \\
\hline
\end{tabular}

Notes: 1 : product liability only;

2: no punitive damages in medical or legal malpractice;

3: no punitive damages in various medical malpractice cases;

4: Oregon restricts lawyer fees to be no more than $20 \%$ of the punitive damages award. 5: Utah exempts the awards below $\$ 20,000$.

All states except Missouri require clear and convincing evidence for punitive damages. 
Table 2: Punitive Damages Allocation Schemes

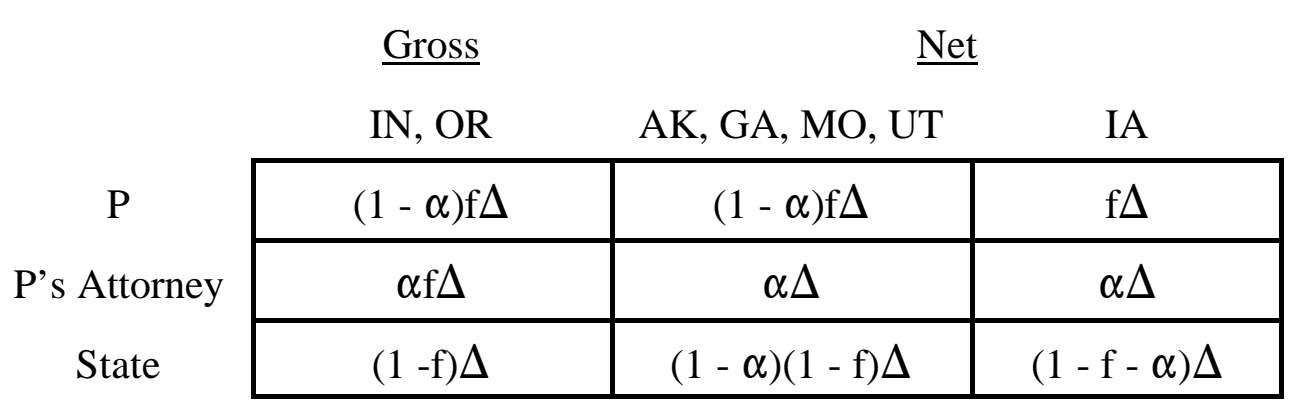




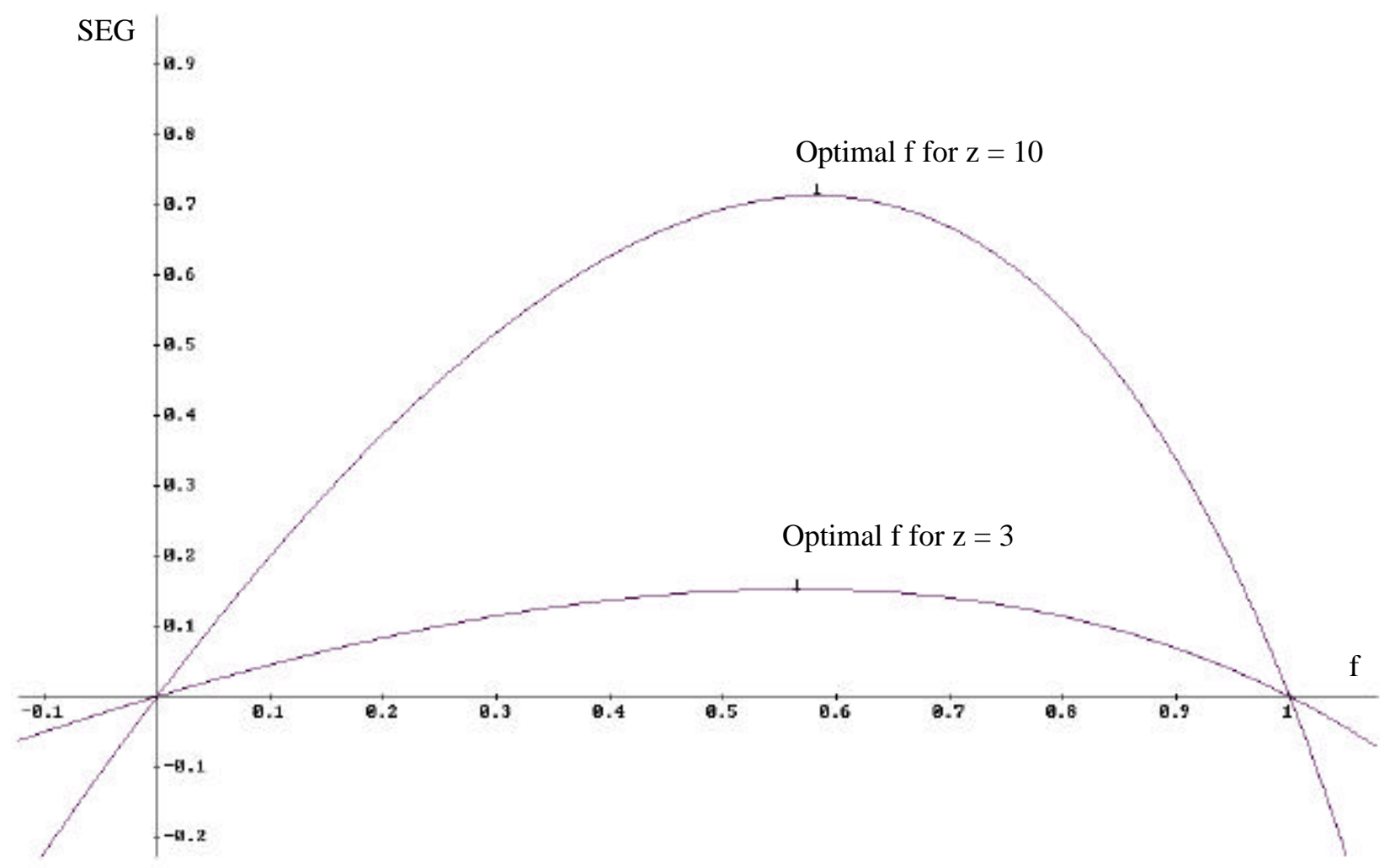

Figure 1: State's Expected Gain in Signaling Equilibrium for Varying $\mathrm{f}$ and $\mathrm{z}$ 


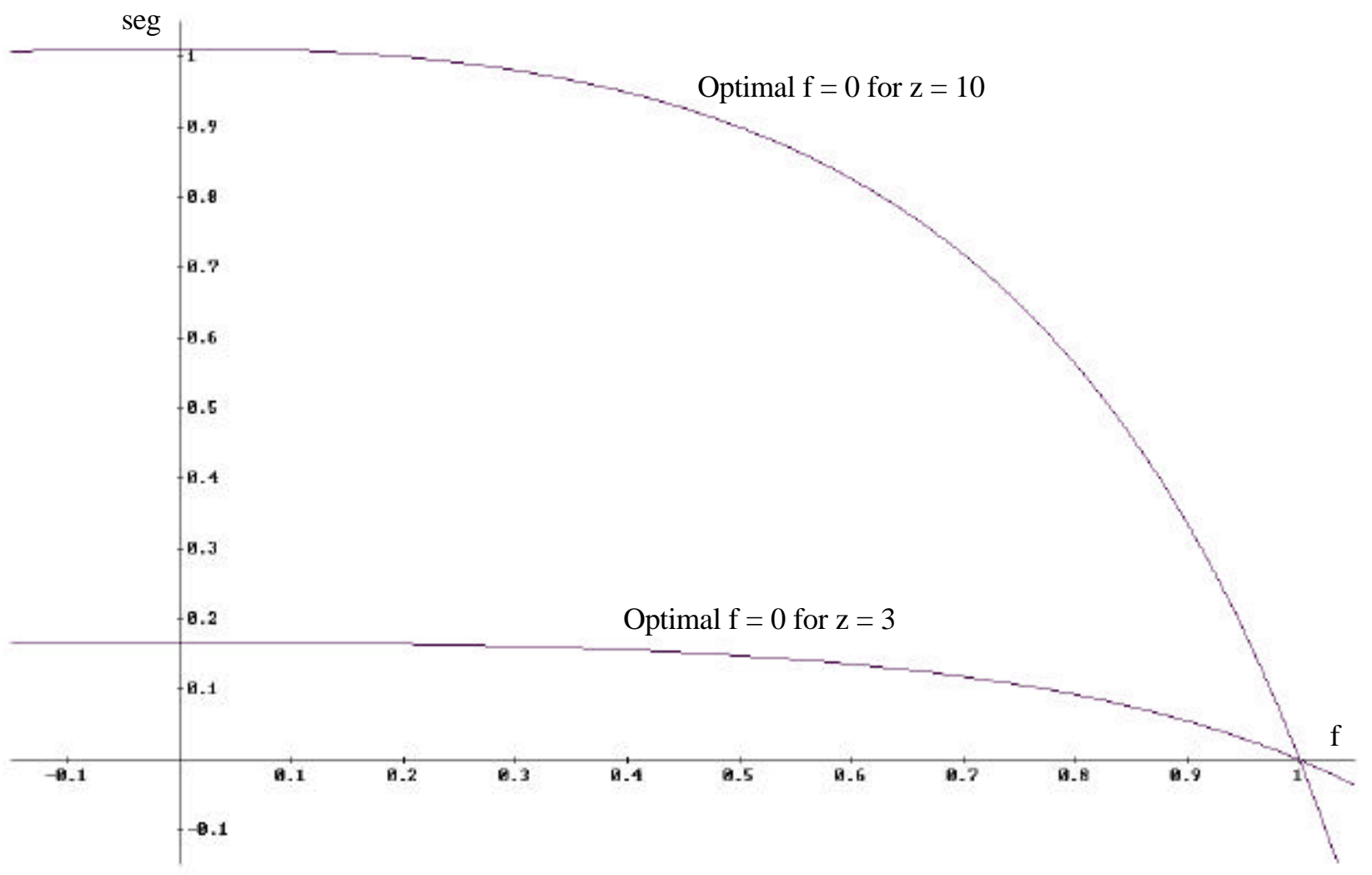

Figure 2: State's Expected Gain in Screening Equilibrium for Varying $\mathrm{f}$ and $\mathrm{z}$ 


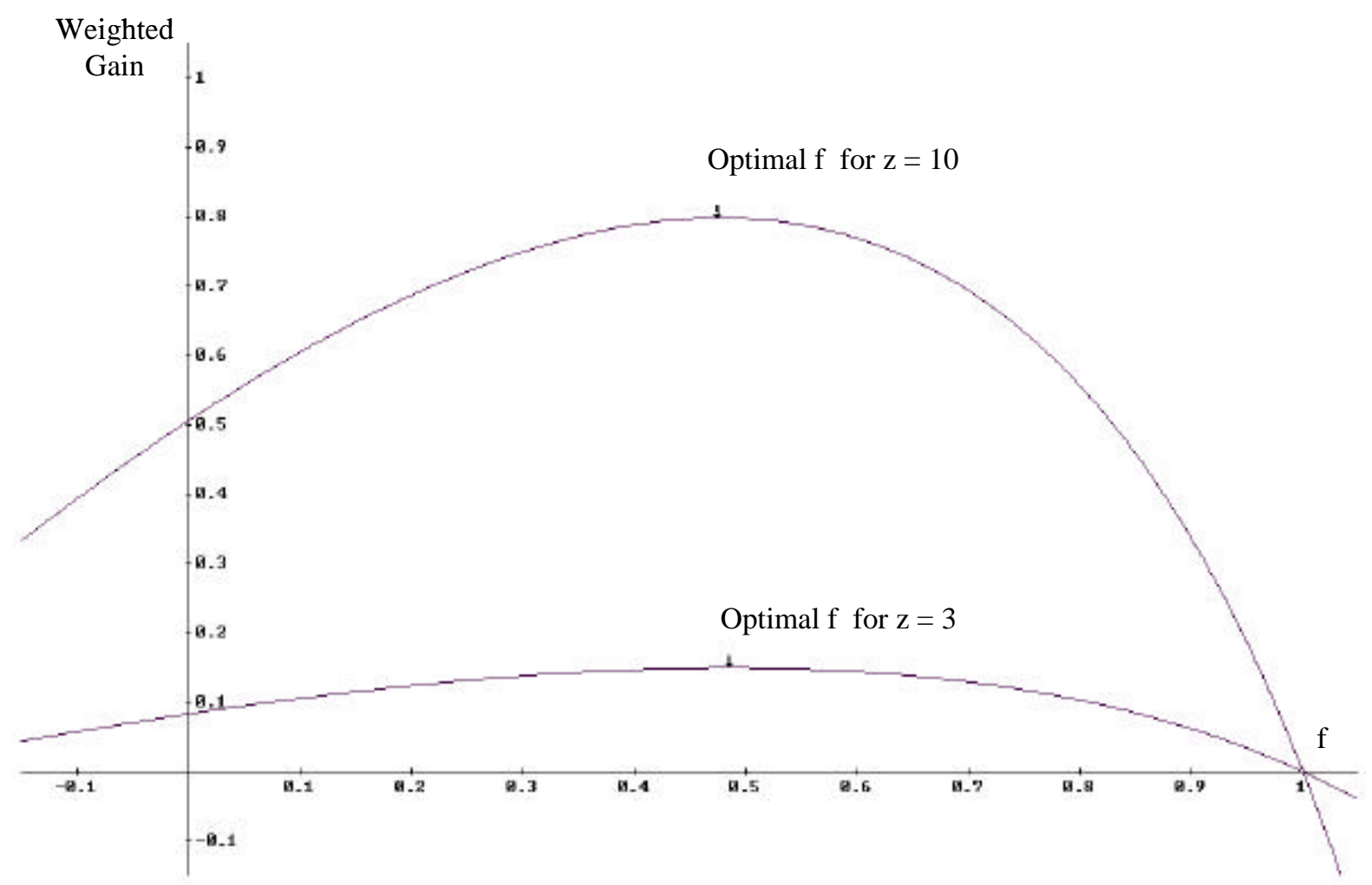

Figure 3: State's Weighted Expected Gain, with $\lambda=0.5$, for Varying $\mathrm{f}$ and $\mathrm{z}$ 


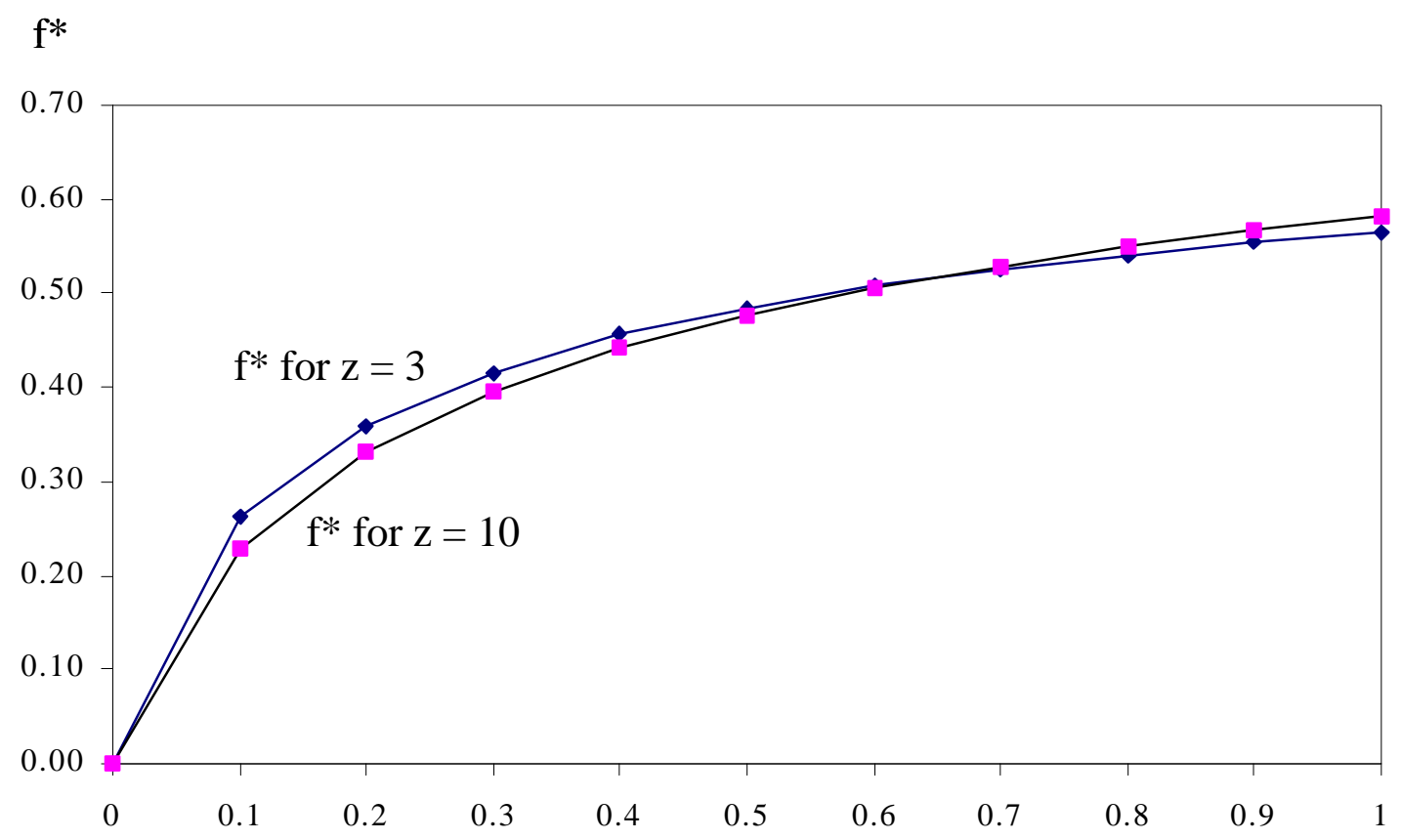

Weight $\lambda$ Associated with SEG(f)

Figure 4: Effect of Weight $\lambda$ on $\mathrm{f}^{*}$ 
PA's expected punitive payoff

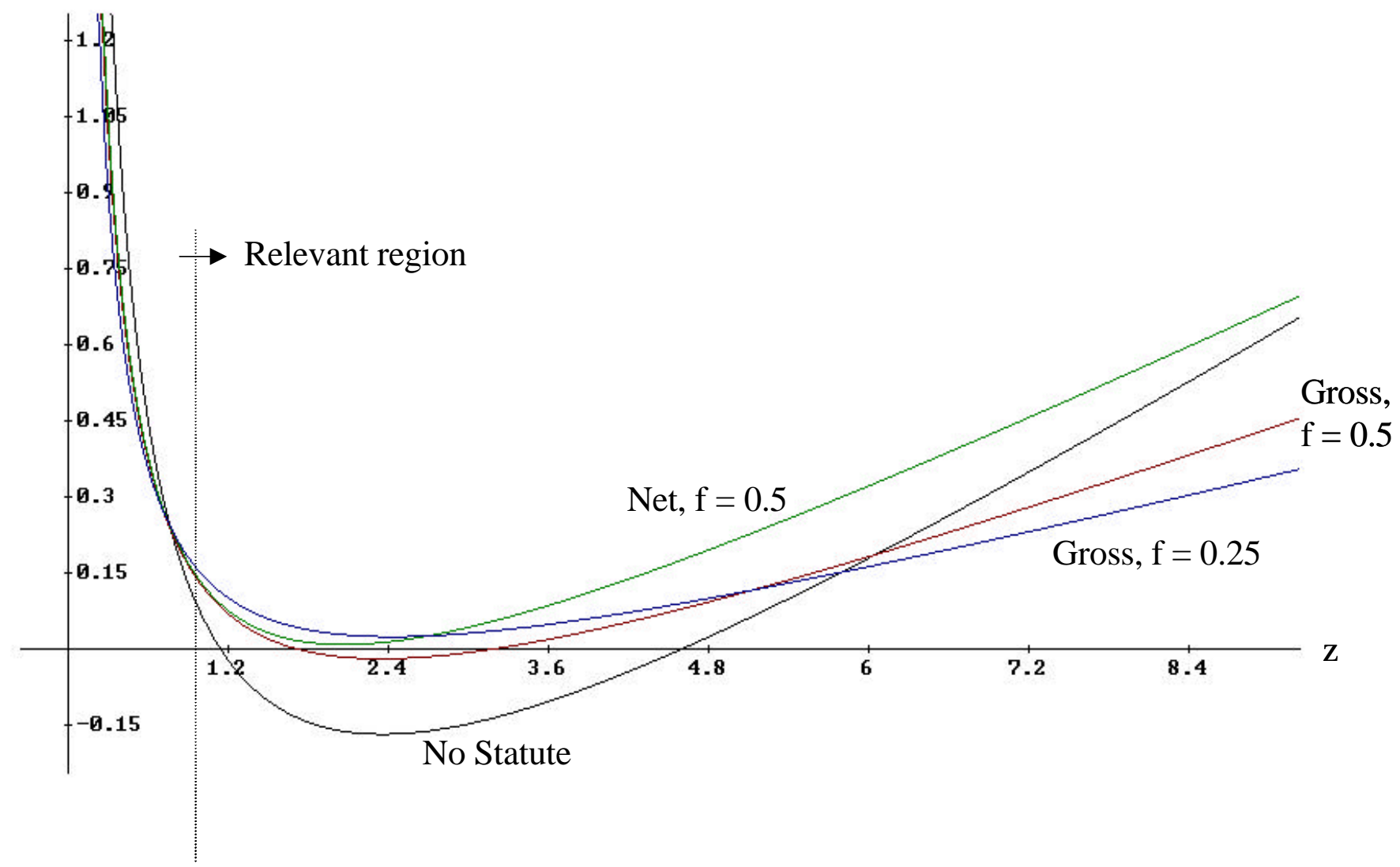

Figure 5: Effect of Statute on Plaintiff's Attorney's Payoff 